\title{
Covid-19 Vaccine and Scholastic Performance of Learners: A Perspective of Internal Stakeholders
}

\author{
Ngwako Solomon Modiba
}

University of Limpopo, South Africa

\begin{abstract}
This paper interrogates the relationship between the availability of the Covid-19 vaccine and the impressive learner results in secondary schools. The paper resulted from diverse discourses, some of which emphasize that the prevalence of Covid-19 in the world has dampened schools' learning moods to the level of flooring learner performance. This paper is conceptual and empirical within the qualitative research paradigm. The question guiding this paper is: to what extent could secondary schools produce inspiring learner results through revelatory information on the availability of vaccination for Covid-19 sufferers? Narrative inquiry and interviewing techniques were used to collect data. Out of the population of 15 secondary schools in one of the circuits in Sekhukhune district in Limpopo Province, South Africa, 3 were conveniently sampled. In each of the 3 sampled secondary schools, only Deputy Chairpersons of the School Governing Bodies and Chairpersons of the Representative Council of Learners became research participants. Findings revealed that underrating the revelatory information of vaccine availability for Covid-19 sufferers was costly for schools. Secondly, failure to consolidate learner solidarity against Covid-19 to improve the quality of schooling life was a problem. Thirdly, the inability by schools to prevent passive teaching and learning through the utilization of the Covid-19 threat. Fourthly, the inability by secondary schools to apply Covid-19 threat to encourage overachievement by learners. Fifthly, inability by schools to push back the frontiers of mediocre performance by applying Covid-19 as a rallying point. Lastly, schools failed to utilize the prevalence of Covid-19 to keep pupils psychologically and developmentally ready for lessons. The researcher recommends applying the ebullient classroom environments to keep teaching and learning memorable, theatrical, and therapeutic, despite the prevalence of the Covid-19 pandemic.
\end{abstract}

Keywords: Classroom Environment, Geared-up, Lethargy, Results, Underrating.

\section{INTRODUCTION}

Eromo (2016) reminds us that no nation develops further than the quality of its schooling. The quality of schooling could be generated by placing an apex priority on an ebullient schooling environment. That has the potential of enabling pupils to concentrate despite the fear of contracting the Covid-19 pandemic. A totality of ebullient classroom environments comprises an ebullient schooling atmosphere. Functional and performing schools are usually aided by how much they molly-coddle their classroom tones. The premise of the shared statement is that it is imperative for schooling in the $21^{\text {st }}$ century to nurture and manage their schooling environments for the benefit of the instructional enterprise, particularly during this tough time of the Covid-19 pandemic. Secondary schools that are not taking the existence of the Covid-19 as an opportunity to keep pupils orderly and disciplined because of the fear of the Covid-19 pandemic are not likely to be functional and thus produce impressive learner results.

The prevalence of functionality and performance as aided by the threat of the pandemic is indispensable for the provision of quality schooling to pupils who are likely to be obsessed with self-development and growth

*Address correspondence to this author at the University of Limpopo, South Africa; E-mail: solomon.modiba@ul.ac.za and thus the development and growth of their nations. Struggling secondary schools need to experiment with reconfiguration as a way of paving the way for the usage of Covid-19 threat to enable them to be competent and operate differently regarding the business of teaching and learning (Siwela, 2017 \& Brown, 2021). To be truly functional and performing, schools need to attempt to prepare their learners for the current century to cope in whatever life environment they find themselves in. The contribution of Covid-19 could be witnessed when pupils display mastery of, among others, problem-solving, innovative, and creative skills. This is possible where learners in a school are provided with more than just cognitivebased learning. This is about secondary school education equipping pupils with relevant holistic competencies appropriate for this century. Transformed schooling environments, as influenced by the Covid-19 pandemic, have the potential to capacitate schools to adequately service learners. Being approached with conviction, Covid-19 influenced schooling environments could alert secondary schools about the danger of treating pupils as being identical. Research proves that to be the biggest single cause of the failure by schools. Secondary schools that perpetually produce impressive learner results are known to be attempting to develop individualized plans for struggling pupils to support and capacitate such learners to be on par with their gifted peers. This is relevant in the current schooling setup where the Covid-19 pandemic 
is holding pupils differently. Such secondary schools would be regarded to be functional and high-performing institutions. Functional and performing secondary schools, which frequently put to good use their schooling environments, are aware that learning by pupils is more than just sitting in a classroom. Furthermore, such schools could be aware that inherited contradictory colonial structures witnessed in myriad secondary schools do not always aid those educational institutions to contribute to the production of competent and dynamic pupils who are likely to cope in an ever-evolving world. Well-managed schooling environments that are embedded within the debate of the Covid-19 pandemic have the potential of reversing dysfunctionality and underperformance experienced by some secondary schools (Siwela, 2017\& Devenish, 2021).

Ideally, all schools need to be opposed to dysfunctionality and underperformance. One of the unpleasant reactions to institutional underperformance, despite the Covid-19 pandemic, is a societal hatred against the perpetually underachieving schools. To revert secondary schools to their glory days, those schools' environments that are appropriately revolutionized have such a capacity and potential. That is why, Bambalele (2019:17) advises that as part of searching for solutions of underachievement of schools, causative factors of underperformance need to be identified. The context of causative here is that which schools are not doing, which could change things for the better. The prevalence of Covid-19 and its vaccine has to impact the interaction between secondary schools and its pupils. Within the Covid-19 pandemic, schooling environments need to encourage the quality of schooling life, inclusive of improving teacher-learner relations. Such relations could engender impressive learner results. Considering that the bulk of current pupils are susceptible to the monotonous pattern of teaching and learning, appropriate utilization of a schooling atmosphere within the Covid-19 setup could address that. Enabling schooling spirit could usher in an outlandish manner of teaching and learning which is largely responsive to the aspirations and values of current pupils despite the Covid-19 threat (Allen 2014:20 \& Dlamini, 2021a).

The thesis of this paper is that the prevalence of the Covid-19 vaccine could enable pupils to feel at ease when at school other than pondering about their safety and security due to this Covid-19 pandemic. Appropriately arranged schooling environments have the potential of triggering impressive learner performance. This is the case because schooling atmospheres have the power of obviating the underutilization of the available teaching and learning time through sharing it with discipline-related matters (Olivier, 2012 \& Dlamini, 2021b). Conducting lessons in a classroom with appropriate air could enable a teacher to foresee what could trigger chaos and disorder and be ready to pre-empt that timeously. Of significance, a classroom environment could ascertain that a teacher changes conditions and circumstances that promote learner misbehavior. That could be done by openly recognizing desirable learner behavior. Such a gesture could motivate a disruptive pupil to abandon such antischooling behavior. Classroom spirits could also encourage that teachers reward desirable learner behavior. A reward received by a learner could inspire her to persist in being an exemplary pupil with the hope of further amassing rewards. This signifies that where pupils congregate with the learner has more influence on their behavior than what they learn. A Covid-19 vaccine could be applied to change the misfortune of a school, such as institutional underperformance into institutional performance. That is why Van Deventer \& Kruger $(2010: 65)$ recount that in the $21^{\text {st }}$ century, secondary school learners perform or underperform based on where they learn and how teaching and learning tasks are executed there. Covid-19 schooling setup distinguishes one school from the rest in terms of learner performance recorded there. Educationally, providing pupils with what they lack and aspire, could have a monumental effect on them to compete favorably with pupils of other institutions in terms of learner results produced. On that basis, managing the Covid-19 schooling environment could be sufficient to generate mouth-watering schooling performance (Levin, 2011:8, Southey, 2012:12). Despite the Covid19 pandemic, secondary school pupils, require to operate in a schooling environment that is vibrant, heart-warming, and indescribably competent for the institutional incumbents to showcase their potentials and talents. In such a schooling environment, teachers are likely to convey an air of serenity to keep nervous pupils calm and focused. This energizes the minds and stimulates creative thinking within the inspiring schooling space (Coetzee, Van Niekerk \& Wydeman, 2011:32, Bodibe, 2012;31 \& Memela, 2012:13). To sum up, exquisite management of the Covid-19 setup prepares pupils psychologically and developmentally ready for the teacher and the lesson to be delivered.

\section{LITERATURE REVIEW}

Owen (2015:150) contends that better management of schooling environment could restore the glory days 
of teaching and learn in school. This signifies that creating an enabling schooling spirit for the successful rollout of the instructional practices ought not to be an option by schooling but an obligation. This is relevant even within the Covid-19 pandemic. This is because of the significance of schooling tone for the prosperity of classroom lessons delivered. The literature review points out that an exquisitely regimented Covid-19 schooling air could prevent a teacher and learners from putting schooling into disrepute in the form of perpetually producing mediocre schooling results (Equal Education, 2018 \& Meador, 2019). This suggests that some secondary schools inadvertently sow a sense of teacher and learner inefficacy in their teachers and learners, a spirit deserving to be eradicated due to institutional dysfunctionality. Where the management of the Covid-19 schooling environment is taken for granted, the underperformance of a school could be prolonged. The literature review indicates that every educational institution's talismanic scholastic learner results reside in that school's classroom environment. As such, they were ignoring to prioritize the management of a school's Covid-19 environment, which could be tantamount to inviting unimpressive learner results. The literature review is unambiguous in emphasizing that Covid-19 schooling environments have a share in the order and discipline experienced in classrooms that have to aid the success of instructional practices. The implication could be that poor academic performance of pupils could be a confirmation of pupils being taught in a classroom empty of an inspiring and stimulating climate. Lara (2019) asserts that an appropriately recreated and refashioned schooling environment has the potential of converting a struggling pupil into an average learner, an average pupil into an aboveaverage learner, and an above-average pupil into a super-learner. This happens despite the existence of the Covid-19 pandemic in schooling. Literature review stresses that what is worth noting about a right Covid19 schooling attitude is its capacity to make learners enjoy being with a teacher. That could be a good point of departure to influence pupils to be sufficiently studious and teachable. Where schooling overflows with such learners, impressive learner results would dominate the educational landscape without sharing the space with learner under-achievement (Gqirana, 2016, Juan \& Visser, 2017). Schooling is so complex that making predictions concerning what orchestrates pupil-underperformance in one school may not necessarily be the case in another. This underlines the reality that an inducing schooling environment is known to impact the academic achievement of learners. Based on this, the literature reviewed abundantly emphasized that the diversity of factors in an educational institution could be behind the impressive learner results. This issue of the multiplicity of factors behind the good scholastic performance of learners implies that adequate attention has to be put to an enabling schooling climate (Adair, 2006 \& Ramrathan, 2017). The literature review reveals that during this Covid-19 pandemic, some schools produce unimpressive learner results based on inappropriate schooling leadership styles exercised in those educational institutions. This suggests that much as an enabling schooling environment is essential in producing impressive learner results, the environment requires the support of an appropriate Covid-19 schooling leadership. Apart from the nature of the schooling leadership practiced in a particular educational institution, there is a need for teachers to allow being guided by classroom environments that prescribe that pupils should never be treated as being identical in a classroom (Zhu, Devos, Li, 2011 \& Dludla, 2021). Failing to acknowledge the heterogeneity of pupils inside a classroom with or without the covid-19 pandemic could prevent the preparation of individualized plans to support struggling pupils to be on par with their gifted peers.

The literature review attests that any educational institution opposed to teacher and learner- mediocrity is likely to orchestrate and facilitate sustainable teacher and learner excellence in an enterprise of teaching and learning despite the prevalence of the Covid-19 pandemic. Literature review reveals that for educational institutions to produce impressive learner results persistently, they require meaningful classroom spirits which encourage the recognition and reward of desirable learner behavior at all times. That kind of behavior is what is missing in most secondary schools, especially during this Covid-19 era. The literature review plainly states that within the Covid-19 pandemic, it takes a super-teacher operating within an enabling schooling environment to convert an ordinary pupil into a super-learner with a brilliant scholastic achievement (Masondo, 2015 \& Hosken, 2021). Literature review reminds us that the biggest single cause of failure in many secondary schools is the inability to create classroom environments where impressive learner results of schooling started. Well management classroom atmospheres, particularly during the Covid19 pandemic, are known to be capable of preventing passive teaching and learning, which could be the 
source of unimpressive learner results. Literature review indicates that classroom lessons delivered when pupils are psychologically and developmentally geared up to learn likely to be successful because of a teacher and learners being ready for those lessons (Kayana, 2021, Keeton, Fokazi \& Farber, 2021).

Furthermore, a stimulating schooling environment, especially during the Covid-19 pandemic, is a reminder that teachers and learners are not assembled in a school to revel. Still, for the mutual construction of knowledge, it's dispensing by a teacher and acquisition by learners. This, therefore, calls for the mollycoddling or taking good care of a Covid-19 schooling environment, given it serving as a vehicle for the successful delivery of a classroom lesson to its recipients. Teaching and learning in a well-managed Covid-19 schooling climate are likely to be unique and productive for the sake of replacing poor scholastic learner results. Literature review advises that this is not likely to be as simple as it sounds, especially with the generation of secondary school pupils and teachers, populating schools. The quality teacher-learner relations characterizing a particular classroom could contribute to the recreation and refashioning of an appropriate classroom milieu that helps produce impressive learner results (Lara, 2018) \& Khaas, 2021. The literature review on the contribution of the Covid19 vaccine to excellent learner results was conducted mainly from public secondary schooling.

\section{OBJECTIVES AND THE RESEARCH QUESTION}

This paper interrogates the relationship between the availability of the Covid-19 vaccine and the impressive learner results in secondary schools in Limpopo Province. The second objective relates to making classroom lessons memorable, theatrical, and therapeutic by utilizing an enabling schooling milieu that puts every learner at ease despite the existence of the Covid-19 pandemic. Based on the expressed objectives, the research question guiding this paper is: to what extent could secondary schools produce inspiring learner results through revelatory information on the availability of vaccination for Covid-19 sufferers? Ongoing lack of impressive learner results could descend a school into the category of institutional dysfunctionality (Equal Education, 2018 \& Meador, 2019).

\section{Research Design}

This paper is a qualitative case study. The problem this paper pursues, namely, dissatisfaction with an educational performance by learners due to fear of contracting the Covid-19 pandemic during schooling, necessitated the design of this paper. Furthermore, the objective of this paper, which is to interrogate the relationship between the availability of the Covid-19 vaccine and the impressive learner results in secondary schools, necessitated that this paper follows a qualitative research paradigm as against the quantitative one. The reality triggered the choice of the qualitative methodology that this paper underscores by Interpretivism and the Learning Organisation Philosophy (Moloi, 2005 \& Khamango, 2021). The researcher saw a need for synergy between the two mentioned theoretical perspectives and the qualitative approach as the overriding research methodology. The combination of the three helped immensely in illuminating issues of Covid-19 and vaccine availability within the schooling setup from the perspective of the impressive learner results by public secondary schools (Clark, 2010 \& Equal Education, 2018). The researcher utilized the theoretical perspectives to interrogate the relationship between impressive learner results by secondary schools and the availability of the Covid-19 vaccine in the schooling terrain. In addition, the researcher utilized the mentioned theoretical perspectives to interrogate the genesis of the dampened learning moods by pupils to the level of flooring their academic performance due to the prevalence of Covid-19 in schooling. This applies to myriad public secondary schools in Limpopo Province. It was amalgamating Interpretivism and the Learning Organisation Philosophy within the qualitative research paradigm aimed at maximizing the strength of the three perspectives, to comprehend in its entirety the contribution of the availability of the Covid-19 vaccine to the impressive learner results by public secondary schools (Ramrathan, 2017 \& Kuzwayo, 2021). The combination of the three also enabled the researcher to understand how despite many years of independence in South Africa, there are still secondary schools whose learner results are far from being impressive. Such an in-depth insight is necessary to operate from an informed position regarding perennial underachievement in some public secondary schools, which earns the affected schools a label of being dysfunctional institutions. Out of the population of 15 secondary schools, 6 were conveniently sampled.

In each school, a Deputy Chairperson of the Scholl Governing Body and the Chairperson of the Representative Council of Learners became research participants. To conclude this item on the research 
design, there is a need to divulge that utilized the narrative inquiry and the interviewing techniques continued to generate data for this paper. To be precise, secondary school SGB Deputy Chairpersons and Chairpersons of the Representative Council of Learners were given an opportunity of narrating from their angles the relationship between impressive learner results and the availability of Covid-19 vaccine in schooling terrain. In addition, SGB Deputy Chairpersons and Chairpersons of the Representative Council of Learners were allowed to share what they regarded as invaluable inputs on impressive learner results and Covid-19 vaccination (Madonsela, 2021). To corroborate and triangulate the gleaned data, interviewing with those research participants provided narrative inquiry. Altogether, 6 research participants were interviewed regarding their perspectives on impressive learner results and Covid-19 vaccination. Interviewing responses were audiotaped for transcription purposes later on. Both the narrative inquiry and interviewing were helpful in terms of accessing information germane to Covid-19 vaccination and impressive learner results (Meador, 2019).

\section{FINDINGS}

The findings arrived at in this paper are about the research topic whose focus is interrogating the relationship between the availability of the Covid-19 vaccine and the impressive learner results in secondary schools in Limpopo Province. The basis of the findings is the analyzed data generated through the narrative inquiry and the interviewing technique. Interrogated responses of the 6 research participants were regarding the relationship between impressive learner results and the availability of the Covid-19 vaccine within the schooling terrain, as part of sharing and discussing the findings in a clear and free from ambiguity fashion. The 6 research participants interviewed in this paper are Respondent A, Respondent B, and Respondent C, referring to Deputy Chairpersons of School Governing Bodies, and Respondent D, Respondent $E$, and Respondent $F$ referring to Chairpersons Representative Council of Learners. That was done to protect the actual identities of those research participants. The researcher sampled those research respondents for interviewing in the area of impressive learner results and Covid-19 vaccine from the perspective of public secondary schools. Concentrating only on the secondary schools, it ought not to create an impression that every time there is pupil-underachievement in secondary schooling, it could be due to the absence of vaccinations in schools.
Schooling is too complex to be taken so simplistically. A host of factors and variables are likely behind the failure to produce impressive learner results by schools (Botha, 2017, Juan \& Visser, 2017 \& Makamedi, 2021). Because of impressive learner results of secondary schools having being debated from diverse angles, this paper needed to choose to discuss such from the angle of Covid-19 vaccination as part of breaking the monotony (Lara, 2018, Meador, 2019, Rush, Duku, Glover, Kiggundu, Kola, Mislav \& Moorost, 2019). In partnership with the qualitative research paradigm, Interpretivism and the Learning Organisation Philosophy have been sufficiently instrumental in assisting in analyzing data to emerge with these findings ultimately. This paper's findings and discussion are the following: Underrating the availability of the vaccine, consolidating learner solidarity, passive teaching, and learning, encouraging learner overachievement, pushing back frontiers of mediocre performance, and keeping learners psychologically and developmentally ready.

\section{DISCUSSIONS}

\section{Underrating the Availability of Vaccine}

Notwithstanding the complexity of schooling, the centrality of Covid-19 vaccination in aiding to produce excellent learner results is evident. The covid-19 vaccine works in tandem with other aspects, such as classroom harmony and learner participation, to ascertain that brilliant learner results are produced. Data abundantly showed that myriad public secondary schools experience plummeting pupil performance where the scare for the Covid-19 pandemic is incredibly high (Bernstein \& McCarthy, 2011:8, Mgxashe, 2011:15 \& Mueller, 2011:8). Relaxed and inviting schooling environments that are fear-free are known to be likable by pupils to make them enjoy being with teachers. In such a learning atmosphere, there is a great likelihood of lessons delivered to learners being successful. That would be evident during the assessment process. On this matter, SGB Deputy Chairperson $C$ of School A remonstrates that "in our current schooling, the number of pupils especially in public secondary schools, who genuinely showcase a passion for their studies is very minimal. As a result of finding themselves receiving tuition in classroom environments that are not inspiring confidence and inducing a desire for learning due to the threat amongst others of the Covid-19 pandemic". RCL Chairperson F of School D asserts that "orchestrating exquisite learner results by our current public secondary school 
pupils could require that classroom spirits engulfing learning sites be made stimulating for learning. Something that could do through mitigating the threat of the Covid-19 vaccine by emphasizing the availability of the Covid-19 vaccine for whoever will contract the virus". Summing up what has been articulated by the two research participants, it is vivid that the era of ignoring and underrating the significance and the contribution of the Covid-19 vaccine during teaching and learning is not now. Clearly, in the current schooling, a classroom ecology plays a noticeable role in enabling classroom lessons' understanding and success. Clarke (2009:3 \& Equal Education, 2018) advise that failing to uproot the spirit of underrating the Covid-19 vaccine to impressive learner results continue to delay the production of brilliant scholastic learner performance as witnessed in myriad public secondary schools. Briefly, enabling classroom environments that encourage learner relaxation and safety from the virus has the potential and capacity of contributing to the production of mouth-watering learner results (Makhura, 2021a).

\section{Consolidating Learner Solidarity}

Public secondary schools have their destiny in their own hands. As such, they have to do their utmost to marginalize hostile classroom environments that are known to be stifling the production of scintillating learner performance. An apposite classroom environment that emphasizes the availability of Covid19 vaccine for whoever could be a victim of the virus is a boon and not a bane inside a classroom in the sense of leading to the right attitude and mentality by both learners and teachers, something that triggers impressive learner results (Lee, 2021). One of the research findings in this paper relates to how a propitious schooling milieu aids in enhancing the quality of classroom life between learners and teachers. Within that kind of quality of life, both learners and teachers are likely to experience quality lesson delivery and reception facilitated by the highest level of cooperation and desire to interact productively. This research finding is supported by an SGB Deputy Chairperson B of School C who reasons that "in our public secondary schools. Nearly all the pupils are not so teachable, which could be deduced from the lowquality teaching and learning environment within which instructional activities are being executed. Something that could reverse for the benefit of all learners in case learner solidarity could be tapped into, particularly during this difficult period of Covid-19 pandemic".
RCL Chairperson D of School E contends that "the quality of engagements between learners and teachers within an enabling classroom air is likely to determine the kind of learner results which classrooms and schools produce and where pupils are exposed to cooperative learning to be able to teach one another. That could strengthen the established learner solidarity, especially during this tough period of the Covid-19 pandemic". The message by these research respondents means that any secondary school that is serious about yielding impressive learner results needs to do its best about consolidation of learner solidarity because this period requires that pupils take care of one another as they embark on their journey of fashioning their future. Clarke (2009:5) advises that a challenge has to be identified in an educational institution, and processes are put in place to formulate solutions based on the cause of that problem. This applies to the lack of impressive learner results due to failing to adequately emphasize learner solidarity (Fomunyam, 2017 \& Meador, 2019).

\section{Lethargic Teaching and Learning}

The literature review aptly demonstrated that memorable, theatrical, and therapeutic lessons presented in an enticing classroom environment are likely to stop monotonous instructional activities. This implies that the delivery of an educational service has to be repackaged invitingly, using a stimulating teaching and learning environment. Where teaching and learning environments are taken for granted, teachers could struggle to replace mediocre lesson delivery, leading to mediocre learning and then learner underachievement. Research evidence confirms that current pupils are in the main resisting schooling, and one of the causative factors is disregarding the setup within which schooling is occurring. Where the site of lesson presentation is dormant and wishy-washy for learners, impressive learner results are not likely to be produced. This could be the case because, in the main $21^{\text {st }}$ century, pupils are susceptible to monotony. The prevalence of the Covid-19 pandemic aggravates this state of affairs. On this point, Deputy SGB Chairperson C of School B reminds that "the preparation of teachers especially for secondary schools who will always bear in mind the importance of diversifying their lesson presentation to pupils within an inducing learning environment, is what current schooling by the nature of learners strongly aspires for, given that Covid-19 keeps pupils ever inconvenienced when at school. Lessons inside the classroom have to be above excellence to drive away learner fear for the virus". RCL Chairperson 
D of School E contends that "no doubt, an enabling schooling environment that generally stimulates the instructional business of the school, is likely to motivate pupils to be studious, which is a precursor to the production of impressive learner results by secondary scholars who are fortunate to be among teachers whose learners are free from lethargy." All the expressed views by the research respondents emphasize how much $21^{\text {st }}$-century secondary school learners aspire to meet in an inducing schooling environment which is likely to improve and enhance learner efficacy. Mkhabela (2011:15) \& Ramphela (2011:21) remind that where public secondary schools lack a fascinating schooling environment, particularly within this scary Covid-19 pandemic, experiencing poor learner results is likely to ensue. Xiadong (2021) articulates that current educational institutions deserve to afford pupils an opportunity of contributing to the eradication of monotonous and boring schooling lessons, which could encourage passive teaching and learning that lead to poor academic learner performance. Particularly during the Covid-19 pandemic, where pupils are ever scared of the virus.

\section{Encouraging Learner Overachievement}

The literature review abundantly indicates that the success of a lesson delivered inside a classroom depends amongst others on the stimulating teaching and learning environment characterizing a particular classroom and the readiness of pupils to learn. This suggests that before the rollout of every lesson, a teacher operating within the enabling classroom climate has to ascertain that all the learners are psychologically and developmentally ready for the lesson. Failure to address the issue of pupils' readiness could lead to the presented lesson being in vain as a result of pupils grasping very little or nothing at all. There are diverse ways of determining the readiness of pupils to assimilate a new lesson. One of that ways is first refreshing the pupils' memories through revising the previous lesson taught. That process is likely to assist in connecting that old lesson to a new one about to be delivered. Adair (2006), Botha (2017) \& Sifile (2021) assert that $21^{\text {st }}$-century educational institutions need to be sensitive to learner under-performance such that every lesson delivered has to be meticulously planned to ascertain its success. On the expressed point, Deputy SGB Chairperson C of School B narrates that "the majority of our public secondary schools fail to register impressive learner results in a consistent pattern as a result of teachers not persistently applying classroom climates to always get all pupils inside the classroom ready for lessons being presented in the form of bearing in mind that this Covid-19 is holding learners differently and there is a need to capture and arrest the minds of all pupils to the lesson for the success of the lesson and its benefit to learners". RCL Chairperson $D$ of School $F$ reiterates that "teaching successfully, learners of the $21^{\text {st }}$ century have to be given less complicated task to do by relaxed and innovative teachers who other than jumping on the presentation of a new topic has to revise the previous topic to get the attention of all learners to the lesson so that when a new topic is introduced every pupil is psychologically and developmentally physically and psychologically inside the classroom to contribute to the overachievement of every pupil with every lesson delivered". Mabote (2008, Ramrathan, 2017 \& Makhura, 2021b)) articulate that every educational institution prescribes either the prosperity or otherwise of lessons rolled out in its classrooms based on placing apex priority on getting every pupil to overachieve with every lesson delivered. This can be successfully done by utilizing the current Covid-19 pandemic as an opportunity to facilitate the overachievement of every pupil with every lesson presented.

\section{Pushing Back Frontiers of Mediocre Performance}

Turner (2000), Bambalele (2019), Motaung (2021,) \& Nkengasong (2021) assert that the best form of deconditioning learners from failure to success is to actively involve them in their studies within a learning environment because schooling is more about pupils than about teachers and other vital stakeholders, either internal or external. One of the findings in this paper is that in many secondary schools, underachievement of pupils is ascribed to pupils being conditioned to mediocre performance. Such a practice is unlikely to eradicate the production of poor learner results (Gae, 2016) \& Makhura, 2021c). Deputy SGB Chairperson B of School C emphasizes that "for impactful learning which leads to impressive learner results to ever occur in a consistent fashion in our secondary schools, there is a need that ourselves as parents, support teachers in their endeavour to de-condition learners under their tutelage from failure to success with the tried and tested notion that success begets success much as failure begets failure, and this could be attempted through taking the current Covid-19 pandemic, as an opportunity for learners and teachers to experiment more with success than with failure in an effort to push back the frontiers of mediocre performance by learners". RCL Chairperson E of School D remarks that "my experience down the years as a learner is that 
schools appear not to be succeeding in pushing back the frontiers of mediocre performance by both teachers and learners through the development of the classroom assertive discipline plans that shall be applied to call to order learners that are naturally disruptive and whose behaviour border on being anti-schooling in nature, because the culture of underperformance in schooling has been left far too long to take root and cannot be uprooted within the shortest space of time of this Covid-19 pandemic". The expressed views explicitly suggest that all learners can learn and progress, although not at the same pace and at the same time. However, mattes are gradually re-conditioning pupils to success than to failure. This is not to underrate the complexity of schooling but to emphasize that where an appropriate schooling air is in circulation within the classrooms, with all pupils behaving in an orderly and decent fashion, every lesson delivered with such pupils has a chance of prospering. Modiba (2012), Gqirana (2016), Lara (2018) \& Mangalothi (2021) sum this eloquently when observing that nowadays, schooling has to try all tricks in the book to get all lessons delivered to pupils successful. The key contributor to the success of classroom lessons is a healthy classroom setting that sharpens the appetite of teachers and learners towards knowledge dispensing and knowledge acquisition, the prevalence of Covid-19 and its scaring capacity in schooling notwithstanding.

\section{Keeping Learners Psychologically and Developmentally Ready}

The literature review is replete with anecdotes that lament how myriad secondary schools incarcerate their chances of good learner performance by failing to transform schooling environments to encourage that before each lesson is rolled out. Every pupil has to be on their tender hooks, ready to absorb and grasp the lesson to be delivered (Mashele, 2021, Mogotlane, 2021 \& Okechukwu, 2021). Crafting an individual plan designed to assist and support struggling pupils to have them on par with their gifted peers also has to be greatly encouraged, especially during this Covid-19 era where some pupils could pull hard to cope. That would confirm that there are likely to be excellent and mediocre learners in every public secondary school. On this aspect, the Deputy SGB Chairperson reasons that "it takes a hero-teacher, to go an extra mile in ascertaining that pupils that are pulling hard with schooling lessons are meticulously identified and have a relevant plan being designed to raise their schooling gap to be to those whose schooling standard is appropriate to the grade they are at." RCL Chairperson
D of School E advises that "scholastic performance in educational institutions resides in the classroom environments of schools and depends on extraordinarily taking good care of the struggling pupils by providing them with an additional lesson to upgrade their standard because the gifted pupils at least could take care of themselves as shown by instant grasping of every lesson delivered especially in an ever enabling classroom ecology." The message gleaned from the respondents is loud and clear about a need first to get all pupils being psychologically and developmentally ready for every lesson shared so that the number of struggling pupils is drastically reduced. Hence Ramphela (2011), Maubane (2021), Mkize (2021), Mokgathe, 2021 \& Moodey (2021) accentuate the need to completely overhaul the South African education system to make it functional and always high performing through appointing super-teachers that are competent and productive among pupils. Some of whom are below par and require additional support to be to the expected standard. Kuseka (2008) \& Rush et al. (2019) advise that secondary schools need to resort to their witticism to equitably service all learners to enable them to produce impressive learner results despite the prevalence of the Covid-19 pandemic.

\section{CONCLUSION}

As displayed in the discussion of findings of this paper, both the review of the literature and the theoretical frameworks played a critical role in talking to the findings of this paper. In addition, the narrative inquiry and the interviewing techniques, together with the theoretical perspectives, provided a better context within which the entire paper had to be located and comprehended. Small wonder that the centrality of the availability of the Covid-19 vaccine and its relationship to impressive learner results were exposed by findings to be the determinant of scholastic learner performance in myriad secondary schooling. The conclusion arrived at in this paper is in the context of the relationship between impressive learner results and the existence of the Covid-19 vaccine to spur schooling on to enhance their academic learner performance in Limpopo Province, South Africa.

\section{RECOMMENDATIONS}

The basis of these recommendations is the discussed findings which are as follows: there is a need for the application of ebullient classroom environments to keep teaching and learning memorable, theatrical, and therapeutic even during the Covid-19 pandemic. In 
addition, educational institutions need to consolidate learner solidarity during the Covid-19 pandemic to enable pupils to take care of one another with their studies. Furthermore, there is a need for schools to replace passive teaching and to learn to make schooling attractive. Moreover, there is a need for schools to encourage the overachievement of learners during this Covid-19 pandemic. There is also a need by public secondary schools to push back the frontiers of mediocre performance by both teachers and learners, especially during this Covid-19 pandemic. Finally, there is a need for secondary schools to ascertain that before the delivery of lessons, especially during this Covid-19 pandemic, pupils are psychologically and developmentally ready to assimilate those lessons. This is necessary to view the perennial underachievement of myriad public secondary schools in Limpopo Province, South Africa.

\section{REFERENCES}

Adair, J. (2006). The John Adair Handbook of Management and Leadership. Leadership \& Organisation Development Journal, 27 (3):235-236). https://doi.org/10.1108/01437730610657749

Allen, J. (2014). As a man thinketh. New York: Dover Publications.

Arden, P. (2013). It's not how good you are; it's how good you want to be. New York: Phaidon.

Bambalele, P. (2019). Rapetsoa acts on violence as he reworks "our cry". Sowetan, 4 October 2019.

Bernstein, A. \& McCarthy, J. (2011). Teachers poor value for money: Incentives for good educators need to be introduced, but the challenge is deeper than training and skills only. The Star, 5 October 2011.

Bodibe, K. (2012). Change is inevitable. Daily Sun, 5 June 2012.

Botha, R.J. (2017). The role of the school principal in the case study of various memebers'perceptioins. Journal of social science, 30 (3): 263-271.

https://doi.org/10.1080/09718923.2012.11893003

Brown, T. (2021). Perez's pandemic allegations have merit. Sowetan, 8 February 2021

Bush, T. Duku, N. Glover,,D. Kiggaundu, E., Kola, S. Mislav, M \& Moorost, P. (2019). External evaluation research report of the Advanced Certificate in Education: .30-School Leadership and Management. Pretoria: Zenex Foundation.

Clarke, A. (2009). The Handbook of School Governors. Cape Town: Kate McCallum.

Clark, D. (2010). Theory $X$ and Theory $Y$, big dog and little dog's performance juxtaposition. Retrieved from Https/Www.Nwlinl.com. Retrieved o4 14 February 2018.

Coetzee, S.A. Van Niekerk, E.J. \& Wydeman, J. L. (2011). An Educator's Guide to Effective Classroom Management. Pretoria: Van Schaik.

Cohen, L. Manion, L. \& Morrion, K. (2007). Research Methods in Education. $6^{\text {th }}$ ed. London: Routledge Falmer. https://doi.org/10.4324/9780203029053

Devenish, G. (2021). SA in a political paralysis. The Star, 6 January 2021.

Dlamini, P. (2021). Enforcement is needed to achieve compliance of Covid-19 regulations. Sowetan, 15 January 2021.
Dludla, S. (2021). Mboweni has herculean task to find funding for vaccine. Sowetan, 16 February 2021.

Eromo, A. (2016). The principal's leadership roles in transforming school culture for quality education at secondary schools of Addis Ababa, Ethiopia. Unpublished PhD thesis, Pretoria: University of South Africa.

Equal Education (2018). School Infrastructure. Www.Equaleducation.Org.Za.

Fomunyam,K G. (2017). The ideological ware as key to improving learner performance. Journal of Education Studies,16 (1):108-125

Gae, W. (2016). Primary school learners' perspectives on factors that impact their learning and wellbeing at school (Unpublished doctoral dissertation). Stellenbosch: Stellenbosch University.

Gqirana, T. (2016). Without resources rural schools will continue to underperform- NGO News 24, 2016.01.06 Accessed on the 30 April 2019. Retrieved from https:/www.news24.com/SouthAfrica/News/withoutresources-rural-schools-will-continue-to-underperform-no20160106. Researchers. Journal of Technology Education, 9 (1):1-16.

Hosken, G \& Keeton, C.. (2021). Warnings a jab sale nears finality. Sunday Times, 14 March 2021.

Juan, A.\& Visser,m. (2017). Home and school environmental determinants of science achievement of South African students. South African Journal of Education, 37(1):1-13. https://doi.org/10.15700/saje.v37n1a1292

Khaas, T (2021). Navigating the treacherous waters ahead. City Press, 26 February 2021.

Kayana, S. (2021). Treaties, law should make vaccines accessible to all. Sowetan, 24 February 2021.

Keeton, C. Fokazi, S. \& Farber, T (2021). Vaccination not an allclear, says prof. Sunday Times, 14 March 2021.

Khamango, T. (2021). Covid-19 pandemic continues to extract a heavy toll on SA. Sowetan, 12 February 2021.

Kuseka, P. (2008). The power within. Sunday Sun, 15 July 2008.

Kuzwayo, M. (2021). Stand up and fight for a fair and just society. City Press, 28 February 2021.

Lara, E.V. (2018). School identity in the modern world. Available at www.Tieonline.Com.Accessed on the 16 March 2019

Lee, N. (2021). Quality education under siege from self-serving school governing bodies. Sowetan, 6 April 2021.

Letlalo, J. (2012). Nothing comes easy in this life. Daily Sun, 18 May 2012.

Levin, W.J. (2011). Why our education system is failing. The Star, 5 October 2011.

Mabote, M.D. (2008). Why Schools Underperform: Some General Causative Factors. Capricorn District. Limpopo Province. An Educational Address During the Curriculum Roadshow Meeting with Mogodumo School Principals in Mogodumo Cluster Gathering. February Madonsela, T (2021). Africa should lead the use of soft power. City Press, 28 February 2021. 16, 2008

Makamedi, L. (2021). SA needs to be educated on how vaccine will work. Sowetan, 28 January 2021.

Makhura, D. (2021a). Fast-track information on vaccines. Sowetan. 27 January 2021

Makhura, D. (2021b). Watch how every cent is spent. Sowetan, 26 February 2021

Makhura, D (2021c). Future-proofing Gauteng. City Press, 7 March 2021.

Mangolothi, B \& Maubane, M. (2021). Information failures in the time of Covid. Sowetan, 15 January 2021

Marishane, R.N. Botha, R.J. \& du Plessis, P. (2011). School Leadership in a Changing Context. Pretoria: Van Schaik. 
Mashele, P. (2021). Broke government with no plan won't succeed with vaccination project. Sowetan, 1 February 2021.

Masondo, S. (2015). How superprincipals and teachers help matrics soar. City Press, 11 January 2015.

Maxwell, J.C. (2014). Good leaders ask great questions: Your foundation for successful leadership. New York: Hachette Book Group.

Maubane, Z. (2021). How Covid-19 is driving permanent technology innovation. City Press, 28 February 2021.

Meador, D. (2019). The role of the principal in school. Accessed from Www. Thoughtco, Com. Accessed on the 22 February 2019.

Memela, S. (2012). Prophetic Intellectual Leaders. Sowetan, 20 June 2012.

Mgxashe, S. (2011). Time for this carelessness with our lives to be stopped, Mr President. Sowetan, 7 December 2011.

Mkize, V. (2021). Why is SA paying so much for Covid-19 vaccine? City Press, 10 January 2021.

Modiba, N.S. (2011). Every Educational Journey has a Destiny. Capricorn District, Limpopo Province. Paper Presented to Motivate all Learners to be Aware that Schooling Days are Numbered, 1 August 2011.

Modiba, N.S. (2012). Every Learner Schools for Himself or Herself not for the Parents. Capricorn District, Limpopo Province. Paper Presented to Motivate Grade 12 Learners to take their studies seriously, 9 May 2012.

Mogotlane, M. (2021). Mahlangu's Africanism a wake-up call. for us. Sowetan, 6 April 2021.

Mokgathe, K. (2021) launch a campaign to teach people more about covid. Sowetan, 11 February 2021.

Moloi, K.C. (2005). The School as a Learning Organisation. Pretoria: Van Schaik.

Moodey, J. (2021). Permanent vaccine is a professional public service. Sowetan, 3 February 2021.

Motaung, T. (2021). SA's rogue politics delayed vaccines. Sowetan, 5 January 2021.

Mouton, J. (1996). Understanding Social Research. Pretoria: Van Schaik.

Mueller, H. (2011). Advocate's Scandal is just a tip of the iceberg. The Star, 5 October 2011.
Okechikwu, K. (2021). Africa can achieve free trade only if ... City Press, 21 February 2021.

Olivier, C. (2012). The DNA of Great Teachers. South Africa: Learning Design.

Omar, Y.A.. (2019). Wanted political entrepreneurs to forge a common nationhood in SA. Sowetan, 4 October 2019.

Owen, J.O. (2015). How to lead: The definitive guide to effective leadership. $4^{\text {th }}$ ed. London: Pearson.

Nkengasong, J. (2021). African nations have begun vaccinating. Sowetan, 29 January 2021.

Ramphela, M. (2011). The culture of impunity. City Press, 14 August 2011.

Ramrathan. L. (2017). Learner poor performance; Provoking Bourdieu's key concepts in analysing school education in South Africa. Southern African Review of Education, 23 (1): 23-36.

Senge, P. Robert, C. Ross, R.B. Smith, B.J.\& Kleiner, A. (1994). The Fifth Discipline Field-book: Strategies and Tools for Building a Learning Organisation. New York: Doubleday.

Sifile, L. (2021). How Prof Karim went from doubter to virus fighter. Sowetan, 5 March 2021.

Siwela, M. F. (2017). Educational stakeholders' contribution towards educating learners-in-totality: A collaborative educational management model for Zimbabwe. Unpublished PhD thesis, Pretoria: University of South Africa.

Southey, C. (2012). Teaching ruin and warring wallahs. Mail and Guardian, 12 April 2012.

Turner, A. (2000). Born to succeed. Britain: The Falmer Press.

Van Deventer, I. \& Kruger, A.G. (eds.) (2010). An Educator's Guide to School Management Skills. Pretoria: Van Schaik.

Xiadong, C. (2021). A promising future for post-Covid cooperation. The Star, 6 January 2021.

Zhu, C. Devos, G. \& Li, Y. (2011). Teacher perceptions of school culture and their organisational commitment and wellbeing in a Chinese school. Asia Pacific Education Review, 12 (2): 319-328.

https://doi.org/10.1007/s12564-011-9146-0

https://doi.org/10.6000/1929-4409.2021.10.171

(C) 2021 Ngwako Solomon Modiba; Licensee Lifescience Global.

This is an open access article licensed under the terms of the Creative Commons Attribution License (http://creativecommons.org/licenses/by/4.0/) which permits unrestricted use, distribution and reproduction in any medium, provided the work is properly cited. 